\title{
Industrial Internet of Things as the Digital Economy Development Factor
}

By

\section{Dr. J.Brekhova}

Candidate of Sciences (Economics), Associate Professor, Deputy DirectorVolgograd Institute of Management, branch of Russian Presidential Academy

of National Economy and Public Administration

Volgograd, Russian Federation Correspondence:brekhova-yv@ranepa.ru

Dr. E.Malysheva

Candidate of Sciences (Economics), Associate Professor, Dean of the Faculty of Economics- Volgograd Institute of

Management, branch of Russian

Presidential Academy of National

Economy and Public Administration

Volgograd, Russian Federation Correspondence:decanecon@vlgr.ranepa.ru

\author{
Dr. I.Kulagina
}

Candidate of Sciences (Economics), Associate Professor- Volgograd Institute of Management, branch of Russian Presidential Academy of National Economy and Public Administration

Volgograd, Russian Federation Correspondence:irinakul@vlgr.ranepa.ru

\section{Dr. E.Timacheva}

Candidate of Sciences (Economics), Associate Professor of the Chair of Economy and Finances of Volgograd Institute of Management, branch of Russian Presidential Academy of

National Economy and Public Administration

Volgograd, Russian Federation Correspondence: borisova_e@mail.ru 


\section{Abstract}

This article is devoted to the analysis of the Internet of things, one of the key transformation forces of contemporary economy indicating the beginning of the forth industrial revolution. Our research is aimed at estimating potential influence of advanced digital technologies on future development of the economy. In order to reach this goal we discovered and estimated the economic effect caused by introducing the Internet of things in its two forms: B2C (consumer) and B2B (corporate, industrial) Internet - as well as determined the difficulties in developing the Internet of things since this technology brings a number of hazards to economic development such as confidentiality problems, cyber-security, absence of common standards, mass layoff of low-qualified personnel. The set of research methods used in the article includes content-analysis of scientific sources, statistics analysis of data concerned with scientific and technical development of domestic enterprises.

On the basis of the obtained results we have come down to the conclusion that digitalization in Russia will require not only increasing investments in digital technologies but as well drastic modernization of the infrastructure of almost all sectors of 
economy. That is why it is necessary to take into consideration the peculiarities of digital technologies developing in our country.

Key words: industrial Internet of things; digitalization; economy; technology; smart things.

\section{Introduction}

Globalization and technical progress make humanity use in doing routine work robots and robotized mechanisms that can be controlled by means of a distant web-server. An obvious technological shift characterized by transition from conventional analog production to "smart production" can be seen in global economy $(5,31)$. This shift can be found in all industries and spheres of the real sector economy. The whole world is covered with the Internet and the speed of transferring data is growing rapidly from year to year. High-speed data transmission $4 \mathrm{G}$ is replaced with 5G-nets. Industrial Internet of Things (IoT - the Internet of Things) is the result of developing these technologies.(12) The main content and goal of the Internet of Things (IoT) is providing users information about physical or virtual objects with predetermined quality of service. Meeting this requirement implies integration of a large amount of information about objects and their identification in the net. Such definition of 
the Internet of Things led to the sharp extending of the net itself and as a result to increasing number of users in the IoT networks.

The predicted growth of the Internet of Things technologies market made up from $\$ 176$ billion in 2016 to $\$ 639,74$ billion to 2022 at average annual growth rate of $25,1 \%$ in $2017-2022$. (13)

In experts perspective the maximum effect from using new technologies of IoT can be obtained in non-oil and gas and non-raw material-based production. According to the rough estimates the effect of using IoT in this sector of economy can exceed 1 trillion rubles (12).Methodology

The article touches upon the main perspectives and problems of developing IoT on the basis of analysis of sources of literature. $(2,4,5,8-10,15,18-20,22,27,28)$, Within the article the opportunities of using IoT industrial paradigm as well as mechanisms of raising effectiveness of industrial production in Russia were analyzed.

\section{Literature review}

At present the networks of the Internet of Things are the most demanded for collecting and transmitting large volumes of information. In this respect IoT networks are studied in many scientific researches by both Russian and foreign scientists. 
However, since the large-scale implementation has been started recently nowadays there is no commonly set terminology. Let's consider some definitions of the Internet of Things.

Internet of things (is an English notion often used as abbreviation IoT) is a conception of a computer net of physical objects equipped with in-built technologies aimed at interaction with one another or with the external environment. (16)

Internet of things (is an English notion often used as abbreviation IoT) is a complex computer system combining local computers, cloud servers, computer nets and material objects (things), that are controlled automatically (excluding human factor) with the help of monitoring sensors and information gathering and processing means.(12)

Industrial Internet of Things (is an English notion often used as abbreviation (IiOT) is the Internet of Things used on an industrial scale at a factory or global corporation for making easier or speeding up the employees work, overall automation of production processes (excluding human influence).(12)

The Internet of things can be considered as a certain stage of Internet development at which the number of "things" connected to the Internet exceeds the number of people using the Internet. The 
Internet of Things combines the objects surrounding people in computer system for exchanging information and providing work without human interference on operational basis. (1)

Implementing the Internet of Things enables transition to individual production meeting requirements of every particular customer.

K. Ashton was the first who formulated the conception of the IoT in 1999. He offered to optimize corporate logistics with the help of Radio-frequency identification tags. The Center of Automatic Identification at Massachusetts Technological Institute developed the architecture of the IoT. The conception is based on combining "things" in the united computing network served by Internet Protocols which enables full automatization of process execution by "things" themselves. (1).

Implementing technologies of the Internet of Things paradigm into production and consumption processes is considered to be the beginning of the fourth industrial revolution - Industry $4.0(5,18$, 19,27). Industry 4.0 in based on "smart production", i.e. products, components and production machines even at the stage when they are being worked out will collect data and exchange it with one another on a real-time basis. Usually the exchange of data implies 
exchange of the most important information for instance about the structure and dynamics of production processes, the volumes of energy consumption, supplies of raw materials, their circulation and etc. Modern "smart enterprises" should easily adapt to constantly changing requirements, technological variations as well as market rules. (27). F. Shruf and et al. described the interconnection of "smart productions" with their consumers. (25).

The following "smart production" technologies are used in the paradigm of the Industrial Internet of Things $(4,13,28)$ :

- intercomputer communication (m-2-m) and smart-devices equipment, mechanisms and facilities (field devices, mobile computing, control devices ), that can interact both with one another and an enterprise's personnel;

- smart-architecture of business-processes - production, management, supply environment of an enterprise supported by IoT,big data and cloud technologies.

- smart-logistics - logistics instruments of optimal flows reacting at sudden changes (such as shortage of materials, insufficient space and etc.).

- smart-energetics - intellectual infrastructure of productions using the IoT should react at changes in energy consumption. 
Economic effect of implementing IoT technologies can be estimated up to 2025 and makes up from $\$ 2,7$ trillion to $\$ 6,2$ trillion per year(7). The contribution of Industrial Internet of Things into World Economy can make up about $\$ 14$ trillion by 2030. ([32). Besides the number of devices connected to it in the countries of Organization for Economic Cooperation will grow from 1 billion (in 2016 ) to 14 billions (by 2022) (21).

For the first time telemetry systems for transmitting data in the Internet were used in transport industry and at hazardous operations industrial facilities. Later the sphere of their application was extended to safe operation management in household use in the systems "Smart house". (14)

\section{Results}

According to international analysts the Industrial Internet of Things (IiOT) is a good opportunity for Russian business to take leading positions in the world.

Many industrial enterprises consider IiOT not only as the way of cutting expenses with simultaneously increasing productivity but as well as the platform for further growth and effective competition in the market. Besides implementing IiOT 
technologies gives new opportunities for control over the systems, processes and centers of knowledge.

However according to consulting company AC\&MConsulting: the growth of Russian market of IiOT in 2019 appeared to be not so significant as it was expected. According to the expert estimation over the next two years compound annual IiOT market growth rate will not exceed $7 \%$. In researches perspective the value of this market will make up about 81 billion rubles by the end of 2020 (6). It is caused by the digitalization of Russian economy.

\section{Discussion}

As any other innovation the Internet of Things has a number of advantages and disadvantages.

The undoubtful advantages of using Industrial Internet of Things comprise the following:

1. Labour saving by means of automatization;

2. Distant control over whole enterprises with minimal number of employees at maximal capacities; 
3. Automatic predicting and calculating efficiency indices, production capacities, equipment life expectancy and efficiency;

4. Complex protection of data bases stored at a distant cloud server;

5. High mobility and speed of data transmitting by means of using the latest communication opportunities of 5Gnetworks;

6. Round-the-clock automatic monitoring of enterprises' operational work;

7. Instant access for administrative staff and members of the Board of Directors to any information concerning the enterprise;

8. Significant extending of the information base in different spheres for further usage.(24)

9. The above mentioned advantages lead to improving quality of life, increasing life security, improving environment and optimization of using natural resources, minimization of risks at hazardous productions. 
However implementing the Internet of Things can lead to some negative consequences to which above all we can refer the following:

1. Job slashing;

2. Threat to consumers personal privacy;

3. Considerable material costs (connected with equipping an office or a house, setting touch sensitive tools);

4. Security problem;

5. RFID-technologies (radio-frequency identification ) can negatively influence both the environment and human health. RFID-antennas are likely to be the source of radiation;

6. Increasing the difference in standard and quality of life among the groups of population as well as countries.

In a whole it is expected that the implementation of the Internet of Things will lead to creating some new more modern vacancies, special opportunities for business development as well as for development of human capital. (24)

Developing of the IoT technologies is mainly determined by the structure of economy of different countries. The analysis 
of the conditions of using the Internet of Things in different countries showed the following results presented in the table. (табл. 1):

\begin{tabular}{|l|l|l|l|}
\hline Region & $\begin{array}{l}\text { Volume of } \\
\text { investments into the } \\
\text { Internet of Things } \\
\text { development } \\
\text { (USD)billion }\end{array}$ & $\begin{array}{l}\text { The size of the } \\
\text { Internet of } \\
\text { Things market } \\
\text { (billion USD) }\end{array}$ & $\begin{array}{l}\text { The number of } \\
\text { objects connected } \\
\text { to the Internet of } \\
\text { Things (billion } \\
\text { items) }\end{array}$ \\
\hline Europe & $\begin{array}{l}185,25 \text { (or 25\% of } \\
\text { investments } \\
\text { obsolete technology } \\
\text { funds) }\end{array}$ & 378 & 5,77 \\
\hline The USA & $\begin{array}{l}14,9 \text { (as of 2018 the } \\
\text { maximum volume of } \\
\text { investment capital) }\end{array}$ & 147 & 0,887 \\
\hline Asia & USD 19,71 billion & 583 & 8,98 \\
\hline
\end{tabular}

Table 1. Indices of using the Internet of Things in different regions of the world in 2018

European region is the leading one by the investments in the sphere of the "Internet of Things", it also has the larger number of objects connected to the Internet of Things (that makes up 5,77 billion items). The USA has minimal volume of investments.

There we can find cause-and-effect relation that leads to a 
small number of the Internet of things ( 0,887 billion items). (17)

According to international company Gartner rates of growth of the IiOT are increasing from year to year exponentially. This process is supported by a large number of devices with direct access to the global network. According to the estimates made by specialists of the consulting company Cisco, nowadays there are up to 7 different interactive mobile devices working in on-line mode per every person.

According to the results of the analysis of the research center CAGR average annual rates of growth of the world market will make up $14,4 \%$ over the period from 2017 to 2023 that in cash equivalent makes up over $\$ 700$ billion per year.

According to alternative predictions made by the agency Machina Research the market of world IiOT by 2025 will grow up to $\$ 484,5$ billion per year that will make up $11 \%$ of the total volume of the market of the Internet of Things that in its turn will make up $\$ 4,3$ trillion. Over the same period of time.

The most demand for and development of the IioT is predicted in such industries of economy as: heavy machine building; medicine and health care, transport, housing and public utilities; «smart city». (12) 
There are a lot of example of implementing Industrial Internet of Things at national level (for instance implementing of smart meters in Germany(23) as well as at the level of an enterprise (ERP-system for creating a smart factory at B\&R Industrial Automation in Austria and etc. (26)

Russia is among the countries where the IiOT is actively developed .

There is the number of peculiarities for the Internet of Things in Russia both positive and negative.

On the one hand there is full provision of the country with low value electric and energetic resources. On the other hand the rate of penetration of the Internet of Things into the Russian way of life is considered to be minimal. This is in its turn caused by the number of reasons: awesome difference between companies in the level of implementing IT-technologies; more rampant development of some industries in comparison with the other, at that such industries as transport and communication are the most quickly increasing and developed. Their growth is also determined by implementation of the Internet of Things in reproduction process. The volume of investments in the sphere of the Internet of Things on the part of enterprises of communication and transport is 
estimated approximately as $1,56 \%$ of the GNP contributed by these spheres into the GNP of the country.

The authos of the report The World Bank highlight that one of the significant achievements of Russia is active development of "digital services" (they are consumed by approximately и 80 million people). (29)

The experts consider that the maximum effect from using new technologies of the IioT can be reached in the industries connected with raw material production as well as oil and gas extracting industries. According to the approximate estimations the effect of using IioT in this sector of economy can exceed 1 trillion rubles. Such industries as agriculture, transport logistics also follow this trend. The potential flow of additional finances can reach 600 billion rubles.

At the last presentation of the opportunities of the wireless connection 5G, within promoting federal project "Digital economy", the representatives of «Rostech» informed us about advantages of implementing cybertechnologies of the Internet of Things in industrial and state sectors. They also previewed contour map of gradual implementation of IioT into all sectors of Russian economy. 
To the main factors fostering the growth of the IoT in Russia can be referred the following :

- Perspectives of global implementing of the IioTtechnologies in all spheres of life;

- Instantly increasing volumes of consumption and demand for new technological decisions;

- State sector support;

- Developing communications of mobile networks;

- Partnership with transnational companies and adopting international experience;

- Demands for absolutely new complex decisions for the systems of production security.

To the main factors preventing the growth of the IoT in Russia can be referred the following:

- Exceeding globalization;

- Bureaucracy in state sector;

High competition at international markets;

Obsolete technologies at most enterprises;

Harmful impact on the planet environment; 
International economic sanctions;

Instable economy;

Decreasing number of investors;

The lack of specialists;

Geographic and natural conditions. (11)

However this technology can cause some hazards: confidentiality, cybersecurity problems, absence of unified standards, mass layoffs of low-qualified personnel.

With extending the number of Internet-connected gadgets the risks to cybersecurity will increase. In 2015 in Russia there were 15,5 million «Internet-connected» gadgets; in the medium-term perspective their number will increase up to 400 million gadgets. I.e. 400 million digital gadgets can either become the source of threat to personal data or can become an instrument for initiating DDoS-attacks. That is why with the development of the IioTtechnologies companies should work out the strategy of providing security and data protection as well as create proper infrastructure. (30) Within the global research of the trends in the sphere of information security in 2017 about $25 \%$ of respondents confirmed the fact of hacker attacks of IioT components used for automatization of technological processes in integration systems. 
However only one forth of respondents is planning to invest in information security of the Internet of Things.

\section{Conclusion}

Digitalization as a whole and implementation of the Industrial Internet of Things in particular will require the increase of investments into digital technologies as well as drastic modernization of infrastructure of almost all sectors of economy. Besides it will require taking into consideration developmental challenges of the IioT in Russia, such as:

- structural and technological inferiority of the Internet of Things in Russia Ėíòåoiåòà âåùåé â Đîññè̀;

- priority spheres of implementing the Internet of Things: production spheres (extracting and processing), communication and transport. State administration can also be referred to priority spheres. Data of the nasty growth of the IioT market value confirm the global perspective of major robotization of production processes.

\section{Bibliography:}

1. Alalvan .R.D., Belyaeva J.A., Smirnova A.A. Russian market of the Internet of Things - Economy and business: theory and practice, №11 - 2017.) 
2. Aletdinova A.A., Artemova N.E. Prospects for the use of the Internet of things in the agroindustrial complex of Russia //Innovations and food security. - 2016. - № 1. - P. 93-98 (In Russian).

3. Altukhov A.I., Dudin M.N., Anischenko A.N. Problems of market economy. - 2019. - № 1. - P. 58-66.

4. Azevedo A., Almeida A. Factory templates for digital factories framework // Robotics and Computer-Integrated Manufacturing. 2011. Vol. 27. No. 4. P. 755-771 (In Russian).

5. Bogovic, A.V., Sandu I.S., Dudin M.N., Lyasnikov N.V. Development of information, communication and Internet technologies in the agricultural market //APC: economy, management. - 2017. - № 10. - P. 34-44 (In Russian).

6. «Digital consumption tunnel»: peculiarities and perspectives of Russian market of the IoT - 2019. [Electronic resource]: http://pltf.ru/wpcontent/uploads/2019/02/internet_veschey_v_rossii_10_02 _2019.pdf(Access date: 13.02.2020)

7. Digital globalization: The new era of global flows. Report, McKinsey Global Institute, February 2016 / J. Manyika [et 
al.]. [Electronic resource]: www.mckinsey.com/businessfunctions/digital-mckinsey/our-insights/digitalglobalization-the-new-era-of-global-flows (Access date: 13.02.2020)].

8. Fedyakova N.N. The use of modern information and resource-saving technologies in agriculture in the region //Regionology. - 2017. - № 2 (99). - P. 187-199 (In Russian).

9. Garetti M., Taisch M. Sustainable manufacturing: trends and research challenges // Production planning \& control. 2012. Vol. 23. No. 2-3. P. 83-104.

10. Gulin K.A., Uskov V.S. On the role of the Internet of things in the transition to the fourth industrial revolution //Problems of territory development. - 2017. - № 4 (90). P. 112-131 (In Russian).

11. Industrial Internet of Things in Russia. Research. TAdviser and SC "Rostech" - 21.05.2018 URL: http://www.tadviser.ru/a/410570 (Access date 12.02.2020)

12. Промышленный интернет вещей в России и в Мире Future2Day,2019. [Electronic resource]: https://future2day.ru/iiot/ (Access date 13.02.2020) 
13. Internet of Things technology market by node component (processor, sensor, connectivity IC, memory device, and logic device), network infrastructure, software solution, platform, service, end-use application, and geography Global forecast to 2022 / Markets and Markets, 2017. [Electronic resource]: https://www.marketsandmarkets.com/Market-Reports/iotapplication-technology-market-258239167. html (Access date 13.02.2020).

14. Kabanova, A. B. Researching the Internet of Things and its using in creating the smart house / A. B. Kabanova, A. A. Bodrov, V. I. Logvin// Simvol nauki. — 2016. — № 11. - P. 73-75.)

15. Kara S., Bogdanski G., Li W. Electricity metering and monitoring in manufacturing systems //Glocalized solutions for sustainability in manufacturing. Berlin, Heidelberg: Springer, 2011. P. 1-10

16. Karen Rose, Scott Eldridge, Lyman Chapin The Internet of things: An overview. - 2015. - C. 8-9

17. Kozlov D.R. Applying the Internet of Things technology in modern world // Bulletin of science and education, 2017. 
$\begin{array}{llllll}\text { № } & 8 & \text { (32). } & \text { P. } & 33-35 \text {. Electronic resource: }\end{array}$ https://cyberleninka.ru/article/n/primenenie-tehnologiiinterneta-veschey-v-sovremennom-mire

18. Lee J., Lapira E., Bagheri B., Kao H. A. Recent advances and trends in predictive manufacturing systems in big data environment // Manufacturing Letters. 2013. Vol. 1. No. 1. P. 38-41.

19. Lipper L. Climate-smart agriculture for food security //Nature climate change. 2014. Vol. 4. No. 12. P. 1068.

20. National environmental rating - 2018. All-Russian public organization "Green patrol". [Electronic resource.] URL: http://greenpatrol.ru/ru/stranica-dlya-obshchegoreytinga/ekologicheskiy-rey ting-subektov-rf?tid=343 (Access date: 10.02.2019, In Russian).

21. OECD digital economy outlook 2015. Paris: OECD Publishing, 2015. [Electronic resource.]: http://dx.doi.org/10.1787/9789264232440en (Access date 13.02.2020).].

22. Ognivtsev S.B. The Concept of the digital platform of agro-industrial complex //International agricultural journal. - 2018. - № 2. - P. 16-22 (In Russian). 
23. Reforming the German energy sector / Metering \& Smart Energy International, 2017. [Electronic resource.]: https://www.metering. com/magazine-article/reforminggerman-energy-sector/ (Access date 13.02.2020).

24. Ryzhkova K.N. the Internet of Things: technology able to change the world // Innovation Science, 2015. №6. P 143146. Access date: https://cyberleninka.ru/article/n/internetveschey-tehnologiya-sposobnaya-izmenit-mir-1

25. Shrouf F., Ordieres J., Miragliotta G. Smart factories in Industry 4.0: A review of the concept and of energy management approached in production based on the Internet of Things paradigm // Industrial Engineering and Engineering Management (IEEM), 2014. P. 697-701.

26. Smart Factory: Industry $4.0 @ B \& R /$ Industrial Internet Consortium, 2016. [Electronic resource.]: http://www.iiconsortium.org/pdf/ BR_Case_Study.pdf (дата обращения 13.02.2020]Технологическое развитие отраслей экономики. Федеральная служба государственной статистики [Electronic resource.]. URL: http: //www.gks.ru/rosstat_main/rosstat/ru/statistics/ economydevelopment (Дата обращения: 13.02.2020) 
27. Technological development of sectors of the economy. Federal state statistics service [Electronic resource]. URL: http://www.gks.ru/rosstat_main/rosstat/ru/statistics/econo mydevelopment (Access date: 13.02.2020, In Russian)

28. The level of development of science and technology in the regions of Russia - 2018. RIA Rating. [Electronic resource.]

URL: http://riarating.ru/infografika/20181017/630109152.html (Access date: 12.02.2020, In Russian).

29. The World Bank, Competing in the Digital Age. Policy Implications for the Russian Federation, 2018

30. Tokareva M.S., Vishnevskiy K.O., Chikhun L.P. Influence of Internet of Things Technologies on the Economy // Busines-Informatika. 2018. № 3 (45). P. 62-78.

31. Tong Ke F. Smart agriculture based on cloud computing and IOT //Journal of Convergence Information Technology. 2013. Vol. 8. No. 2.

32. Uskov V.S. Role of the Internet of Things over Transition to the Forth Industrial Revolution. //Territory Development Problems. - 2017. - № 4 (90). - P. 112-131 
33. Winning the Industrial Internet of Things. How to accelerate the journey to productivity and growth / Accenture, 2015. [Electronic resource]: https://www.accenture.com/usen/ /media/Accenture/ConversionAssets/DotCom/Documents/Global/PDF/Digital_1/ Accenture-Industrial-Internet-of-Things-PositioningPaper-Report-2015.pdf (Access date 13.02.2020).

34. Witchalls C., Chambers J. The internet of things business index: A quiet revolution gathers pace //The Economist Intelligence Unit. 2013. About 